\title{
Evidence of angiotensin II involvement in prolactin secretion in response to hemorrhage in adrenodemedullated and guanethidine-treated rats
}

\author{
L J C Machado, A M Reis and C C Coimbra \\ Department of Physiology and Biophysics, Institute of Biological Sciences and Department of Internal Medicine, Federal University of Minas Gerais, \\ 31270-901 Belo Horizonte, MG, Brazil \\ (Correspondence should be addressed to C C Coimbra, Department of Physiology and Biophysics, Institute of Biological Science, \\ Federal University of Minas Gerais, 31270-901 Belo Horizonte, MG, Brazil; Email: coimbrac@icb.ufmg.br)
}

\begin{abstract}
Objective: The present experiments were designed to investigate the influence of the renin-angiotensin system (RAS) on prolactin secretion in response to hemorrhage $(1.2 \mathrm{ml} / 100 \mathrm{~g}$ body weight (bw)/2 min).

Methods and Results: Male Wistar rats (250-300g) were divided into the following experimental groups. (i) Sham-operated animals submitted to intravenous administration of $\left[\mathrm{Sar}^{1}, \mathrm{Thr}^{8}\right]$-angiotensin II (sarthran), an angiotensin II antagonist $(750 \mathrm{ng} / 100 \mathrm{~g}$ bw as a bolus plus an infusion of $25 \mathrm{ng} / 100 \mathrm{~g} \mathrm{bw} / \mathrm{min}$ over $30 \mathrm{~min}$ ), which did not alter the prolactin secretion in response to hemorrhage. (ii) Animals submitted to adrenodemedullation which by itself increased the prolactin secretion in response to hemorrhage by $274 \%(P<0.01)$. However, sarthran infusion into adrenodemedullated rats completely blocked this increased prolactin secretion in response to hemorrhage $(P<0.01)$. (iii) Intact animals submitted to blockade of sympathetic noradrenergic pathways by pretreatment with guanethidine $(10 \mathrm{mg} / 100 \mathrm{~g}$ bw), which also increased the prolactin secretion in response to hemorrhage by 55\% $(P<0.01)$. This increased prolactin secretion in response to hemorrhage observed in guanethidine-treated rats was completely blocked by sarthran preinfusion $(P<0.01)$. (iv) Adrenodemedullated animals pretreated with guanethidine, which abolished the prolactin secretion induced by hemorrhage.

Conclusions: Our data suggest a role for circulating catecholamines in the prolactin secretion response to stress. In addition, the experiments reported here demonstrate that RAS has a stimulatory effect on prolactin secretion in circumstances in which sympathetic activity or adrenomedullary secretion is suppressed. These are the first data demonstrating that a physiological prolactin secretion response to stress depends on the RAS.
\end{abstract}

European Journal of Endocrinology 146 439-445

\section{Introduction}

Several studies suggest that the renin-angiotensin system (RAS) may modulate endocrine functions, including prolactin release, and participate in the regulation of different physiological processes besides those related to blood pressure and volume. Angiotensin II and prolactin are important stress hormones that are significantly increased in both acutely and chronically stressed animals (1-11). Although angiotensin II may activate the sympathoadrenal medulla and hypothalamic-pituitary-adrenal system, its participation in the control of prolactin secretion during stress has been generally neglected. Angiotensin II receptors have been found in adenohypophysis lactotrophs, thyrotrophs, and corticotrophs (12-14).
These receptors are functional because direct application of angiotensin II to pituitary cells in vitro results in a stimulation of prolactin (12-15). In addition, it has been shown that angiotensin II participates in the regulation of anterior pituitary hormone secretion by acting either directly on the anterior pituitary or indirectly on the hypothalamus. In the anterior pituitary, angiotensin II directly increases the release of prolactin $(12,15-17)$. Indirect effects occur through the hypothalamus and medial preoptic area, where angiotensin II increases dopamine release, leading to a decrease in prolactin release $(15,17-21)$. In addition, a previous study has shown that the angiotensin II receptor $\mathrm{AT}_{1 \mathrm{~A}}$ is predominantly expressed in the rat forebrain and that, in contrast, the angiotensin II receptor $\mathrm{AT}_{1 \mathrm{~B}}$ subtype predominates in the anterior 
pituitary (13). Therefore, neuroendocrine effects of angiotensin II might occur not only at different levels but also through two different receptor subtypes. In adult male rats, about one third of all anterior pituitary cells express $\mathrm{AT}_{1 \mathrm{~B}}$ receptor mRNA. A major part (78\%) of $\mathrm{AT}_{1 \mathrm{~B}}$-expressing anterior pituitary cells is immunoreactive for prolactin (21). Although the possibility that angiotensin II functions as a hormone influencing prolactin secretion in certain physiological conditions has been proposed $(10,12,13,16,17,21,22)$ experimental data have not been present. Recently, it has been found that in vivo stimulation of prolactin release by peripherally injected angiotensin II increases with age, and first responses were observed at 20 days of age in both sexes in rats (12). What makes these observations physiologically meaningful are the data indicating that under certain conditions, notably during hemorrhage, angiotensin in plasma reaches levels that are likely to activate prolactin release (11, $12,17,20,23,24)$.

The present experiments were designed to investigate the influence of the renin-angiotensin and sympathoadrenal system on hemorrhage-induced prolactin secretion. [ $\left[\mathrm{Sar}^{1}, \mathrm{Thr}^{8}\right]$-Angiotensin II (sarthran), an angiotensin competitive antagonist $(25,26)$, was employed to block the effects of angiotensin II. Guanethidine, an adrenergic neuron blocker, and adrenodemedullation were employed as tools to delineate the relative roles of sympathetic innervation and circulating catecholamines in prolactin regulation by the RAS. Since guanethidine is thought not to cross the blood-brain barrier and to have no effect on the cholinergic innervation of the adrenals, it was used to block the noradrenergic brain-peripheral links (27-29).

\section{Materials and methods}

\section{Animals}

Male Wistar rats (250-320g) had free access to Purina rat chow and tap water and were housed under controlled temperature with $14 \mathrm{~h}$ of light $(0500-1900 \mathrm{~h})$ per day. At the age of 11 weeks, the rats were placed in individual cages and handled frequently. One week later, they were anesthetized with ether, and a silastic catheter was inserted through the jugular vein into the right atrium for blood sampling by the technique of Harms and Ojeda (30). This catheter was filled with polyvinylpyrrolidone (PVP) solution and rinsed every 2 days with $1 \mathrm{ml}$ saline containing $25 \mu \mathrm{IU}$ heparin (Liquemine, Roche, Rio de Janeiro, RJ, Brazil). All animals were allowed to recover for one week before being used in an experiment.

\section{Adrenal medullectomy}

After insertion of the jugular catheter, the adrenal glands were sequentially exposed via a dorsal approach.
Each gland was gently retracted with a pair of curved, flat forceps. A nick was then made in one of the poles of the gland with iris scissors and the medulla was extruded by gentle compression of the adrenal body with the flat forceps. Next, to ensure a more complete ablation of medullary tissue the tips of very fine forceps were introduced into the nick and slowly rotated several times inside the gland. Upon completion of this procedure the glands were returned to their normal position and the wound was sutured with cotton thread. In sham-operated rats, the adrenals were handled but not incised. All animals were allowed to recover for a week before being used in an experiment. At the end of the experiments the success of the procedure was checked by examination of the glands.

\section{Experimental design}

On the day of the experiment the rats (adrenodemedullated or sham-operated) had their venous catheter connected to a peristaltic pump one hour prior to hemorrhage. After $30 \mathrm{~min}$, guanethidine (Sigma, St Louis, MO, USA) was given intraperitoneally (i.p.) at a dose of $10 \mathrm{mg} / 100 \mathrm{~g}$ body weight (bw). The same volume of saline solution was administered to the rats not treated with guanethidine. [Sar ${ }^{1}$, $\mathrm{Thr}^{8}$ ]-Angiotensin II (Sarthran, Sigma) was then immediately infused over $30 \mathrm{~min}(750 \mathrm{ng} / 100 \mathrm{~g}$ bw as a bolus plus a continuous infusion of $25 \mathrm{ng} / 100 \mathrm{~g}$ $\mathrm{bw} / \mathrm{min})$. Controls were treated with the same volume of saline $(0.2 \mathrm{ml}$ as a bolus plus an infusion of $0.007 \mathrm{ml} / 100 \mathrm{~g} \mathrm{bw} / \mathrm{min})$. At time zero, sarthran (or saline) infusion was stopped and animals were bled rapidly $(1.2 \mathrm{ml} / 100 \mathrm{~g}$ bw/2 min of hemorrhage). Blood samples $(0.2 \mathrm{ml})$ were collected at $-30 \mathrm{~min}$ (immediately before guanethidine treatment) and at $0,5,10,15$ and $30 \mathrm{~min}$ after the beginning of bleeding. The volume $(0.2 \mathrm{ml})$ was replaced with saline solution after each sampling.

Four experimental groups were used: (i) shamoperated (controls), (ii) adrenodemedullated (ADM), (iii) sham-operated guanethidine-treated (GUA), and (iv) adrenodemedullated-guanethidine-treated rats (ADM-GUA). Each group was divided into two subgroups ( $n=7-8$ animals) intravenously infused with sarthran or saline. Two other groups of animals (saline-treated and sarthran-treated) were similarly manipulated in the absence of hemorrhage.

\section{Processing of samples}

Plasma prolactin was measured in duplicate by radioimmunoassay using materials supplied by the NIDDK (Bethesda, MD, USA). The samples were run in the same assay with a sensitivity of $2 \mathrm{ng} / \mathrm{ml}$ plasma and an intra-assay coefficient of variation of $8 \%$. 


\section{CONTROL (A)}

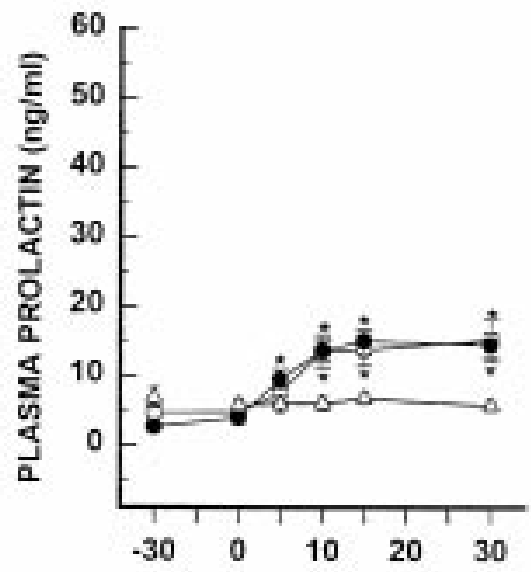

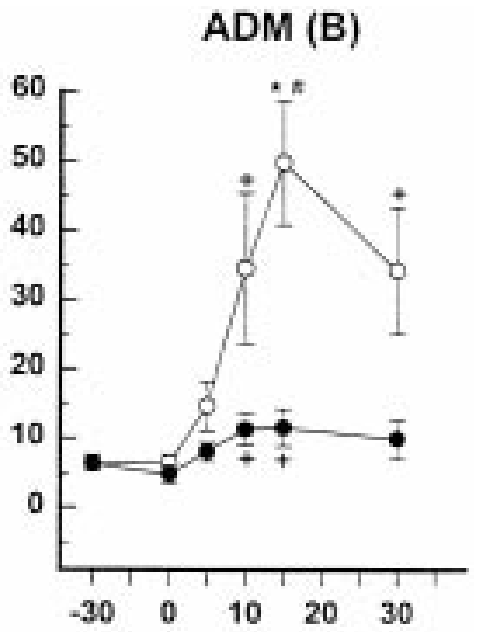

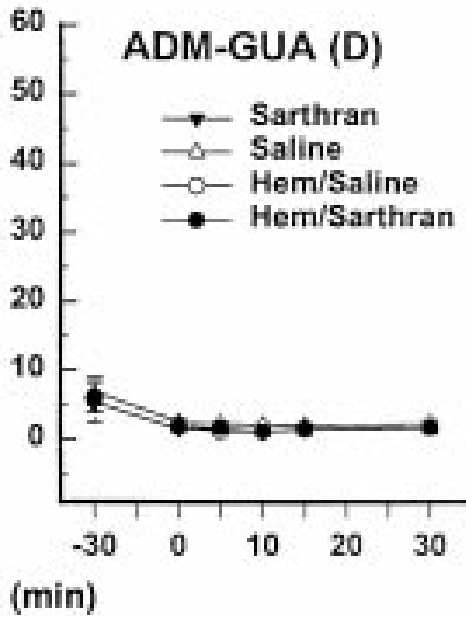

Figure 1 Effect of intravenous administration of sarthran $(750 \mathrm{ng} / 100 \mathrm{~g} \mathrm{bw}$ as a bolus plus an infusion of $25 \mathrm{ng} / 100 \mathrm{~g}$ bw over $30 \mathrm{~min})$ or saline $(\mathrm{NaCl} 0.15 \mathrm{~mol} / \mathrm{l})$ on the hyperprolactinemia induced by hemorrhage (rapid bleeding of $1.2 \mathrm{ml} / 100 \mathrm{~g}$ bw (Hem)) in (A) sham-operated (control), (B) adrenodemedullated (ADM), (C) guanethidine-treated (GUA), and (D) adrenodemedullated-guanethidine-treated (ADM-GUA) rats. Data are means \pm S.E.M. of $7-8$ observations. ${ }^{*} P<0.01$ vs prehemorrhagic values; ${ }^{+} P<0.05$ vs prehemorrhagic values; ${ }^{\phi} P<0.01$ vs saline group; ${ }^{\#} P<0.01$ vs hemorrhage-sarthran group.

\section{Statistical analysis}

Differences between groups (area under the curve) were checked by ANOVA followed by the NewmanKeuls test. Values for samples taken before and after the beginning of hemorrhage were compared with basal values by repeated measures ANOVA followed by the Newman-Keuls test.

\section{Results}

\section{Effect of sarthran administration on basal and hemorrhage-induced prolactin secretion}

As illustrated in Fig. 1A, sarthran administration did not induce any change in basal plasma prolactin levels. However, following bleeding there was an immediate increase in plasma prolactin levels in sham-operated rats. The prolactin release induced by hemorrhage was observed throughout the experimental period when compared with basal values $(P<0.01)$. The increase in plasma prolactin following hemorrhage was not affected by infusion of the angiotensin II antagonist (sarthran, Fig. 1A). The effect of hemorrhage on prolactin secretion was already evident after $5 \mathrm{~min}(P<0.05)$, reaching a peak at $15 \mathrm{~min}$ and persisting throughout the experimental period. Figure 2 shows the 30-min integrated area under the incremental prolactin curve. There was no significant difference in the prolactin secretion response to hemorrhage between intact rats treated with sarthran and intact rats treated with saline (Fig. 2).

\section{Prolactin secretion in response to hemorrhage in adrenodemedullated rats}

In ADM rats, there was a rapid and higher prolactin secretion in response to hemorrhage (Fig. 1B) when compared with intact animals that was observed throughout the experimental period $(P<0.01)$. The area under the prolactin curve showed that adrenodemedullation increased the prolactin response to hemorrhage by $247 \%$ (Fig. 2, P<0.01). Sarthran infusion into ADM rats completely blocked $(P<0.01)$ 
the increased prolactin response induced by hemorrhage to the level observed in intact animals. The inhibitory effect of sarthran on the prolactin secretion in response to hemorrhage in ADM rats was already evident during the first $10 \mathrm{~min}$ after bleeding (Fig. 1B).

\section{Prolactin secretion in response to hemorrhage in guanethidine-treated rats}

In guanethidine-treated rats, hemorrhage induced a rapid and higher prolactin secretion in response to hemorrhage (Fig. 1C) than in control saline-treated rats (Fig. 1A). Guanethidine treatment increased the prolactin response to hemorrhage by $55 \%$ (Fig. 2, $P<0.01)$. This increased plasma prolactin in guanethidine-treated rats in response to hemorrhage was observed throughout the experimental period. However, this increased prolactin secretion in response to hypovolemia was much lower in guanethidine-treated rats than in ADM rats considering the area under the prolactin curve (Fig. 2, $P<0.01$ ). The prolactin secretion in response to hemorrhage of guanethidinetreated rats was already seen at $5 \mathrm{~min}$ (Fig. 1C, $P<0.05)$. Sarthran infusion into guanethidine-treated rats also completely blocked (Fig. 2, $P<0.01$ ) the increased prolactin secretion considering the area under prolactin curve.

Guanethidine pretreatment of ADM rats abolished the prolactin secretion induced by hemorrhage in both saline- and sarthran-infused rats (Fig. 1D, Fig. 2, $P<0.01)$.

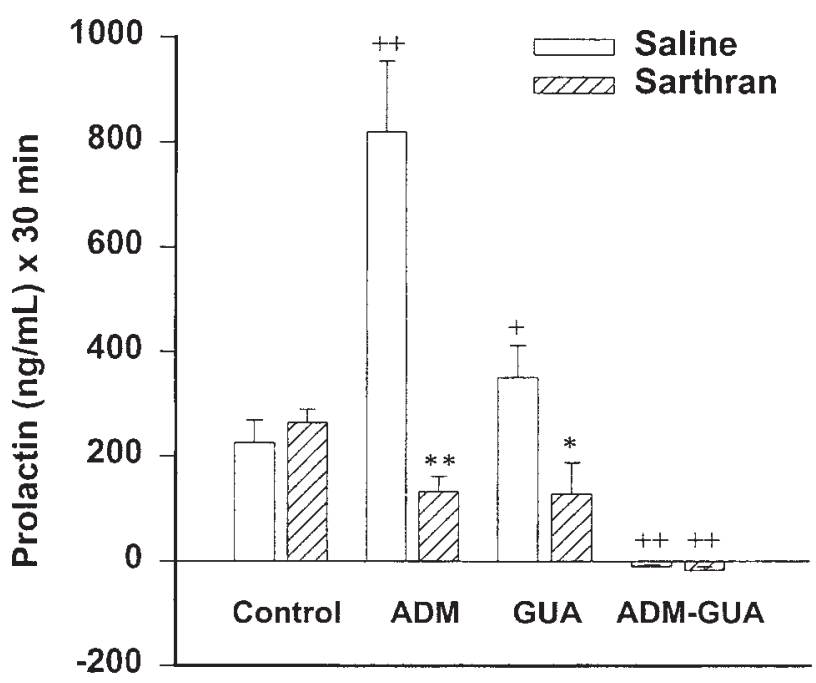

Figure 2 Integrated area under the prolactin curve (shown in Fig. 1) in sham-operated (control), adrenodemedullated (ADM), guanethidine-treated (GUA) and adrenodemedullatedguanethidine-treated (ADM-GUA) rats. Data are means \pm S.E.M of individual areas calculated by the trapezoidal rule.

${ }^{*} P<0.05$ vs saline-treatment; ${ }^{* \star} P<0.01$ vs saline-treatment; ${ }^{+} P<0.05$ vs control group; ${ }^{++} P<0.01$ vs control group.

\section{Discussion}

The experiments reported here show that blockade of the sympathoadrenal system completely eliminates the prolactin secretion in response to hemorrhage. In contrast, the hyperprolactinemic response to hemorrhage was potentiated in rats bearing partial blockade of the sympathoadrenal system, i.e. adrenodemedullation produced a $270 \%$ increase in prolactin response to hemorrhage compared with control, and guanethidine treatment alone induced a 50\% higher hyperprolactinemic response to hemorrhage compared with control. These data suggest a role for circulating catecholamines in the prolactin secretion response to stress. Circulating catecholamines are able to modulate prolactin secretion by both central and peripheral actions - centrally by decreasing the activity of the tuberoinfundibular dopaminergic neurons, and peripherally by increasing renin release which results in an enhanced circulating angiotensin II. Consequently, adrenal enucleation followed by inhibition of the presynaptic sympathetic system by guanethidine treatment would decrease prolactin secretion. This proposal is consistent with the observation that the prolactin response to hemorrhage was completely blocked in adrenodemedullated-guanethidine-treated rats.

Central adrenoceptors are thought to be involved in stress-induced prolactin release (2) and the participation of central adrenergic mechanisms in prolactin secretion has been demonstrated by systemic (31) and intracerebroventricular administration (31-33) of adrenergic agents. Local intracerebral injection of adrenergic agents suggests that adrenoceptor activation in the preoptic-anterior hypothalamus $(\mathrm{PO} / \mathrm{AH})$ and mediobasal hypothalamus stimulate prolactin secretion (33-35). Fuxe and Hökfelt (36) have shown that activation of adrenoceptors by the $\alpha_{2^{-}}$ agonist, clonidine, decreases the activity of the tuberoinfundibular dopaminergic neurons, giving support to at least one mechanism by which increased circulating noradrenaline or adrenaline acting on the hypothalamus may contribute to the regulation of prolactin. In addition, the prolactin release induced by circulating catecholamines could also be attributed to an indirect action of angiotensin II on sympathetic nerve activity $(37,38)$ and/or to a stimulatory effect of this peptide on adrenomedullary secretion (39, 40). Many studies indicate that angiotensin II stimulates both basal and hemorrhage-induced catecholamine secretion. Angiotensin II has a primary role in modulating sympathetic tone and effects through either central or peripheral mechanisms. Centrally, it acts by increasing sympathetic nerve activity (37, 38 ), and peripherally it facilitates noradrenergic transmission by potentiating neurotransmitter release (37, 41 ), inhibiting noradrenaline reuptake and stimulating the release of catecholamines from the adrenal medulla $(42,43)$. The RAS has been implicated in the increased 
secretion of adrenal medullary catecholamines which occurs in response to a variety of stimuli, such as in response to hemorrhage, that can be blocked by an angiotensin II antagonist administered into the cerebral ventricles $(44,45)$ or by nephrectomy $(44,46)$. Therefore, this interaction between the sympathoadrenal system and RAS that occurs during hemorrhage would potentiate prolactin release.

Our results also indicate that, under circumstances in which adrenal medullary secretion is suppressed or when the peripheral sympathetic noradrenergic pathways are blocked, increased activity of the remaining branch of the sympathoadrenal system may compensate and even potentiate the prolactin secretion in response to stress. The increased adrenal medulla activity may compensate for the absence of the noradrenergic brain-peripheral links blocked by guanethidine treatment. On the other hand, an increased sympathetic noradrenergic drive to periphery may compensate for the absence of adrenal medullary secretion. This proposal is also consistent with the observation that the hyperprolactinemic response to hemorrhage obtained in adrenodemedullated animals was completely blocked in adrenodemedullatedguanethidine-treated rats.

Our results are also in agreement with experiments describing an increased hormonal response to hemorrhage in adrenalectomized or sympathectomized rats $(3,4)$. Previous experiments showed potentiated responses to hemorrhage of the vasoactive hormones arginine vasopressin, renin, and noradrenaline in adrenalectomized rats $(3,4)$. In addition, it has been shown that the renin response to hemorrhage is potentiated by 6-hydroxydopamine-induced lesions in the dorsal noradrenergic bundle $(10,47)$. It is well known that the sympathetic nerve might stimulate the juxtaglomerular cells in the kidney to release renin which, in turn, elevates the level of angiotensin II in plasma $(48,49)$. Circulating angiotensin II has been described to stimulate prolactin secretion (12) and its potency in stimulating prolactin release from pituitary cells in vitro is one of the highest among potential prolactin-releasing factors (1). Therefore, during hemorrhage the increased circulating angiotensin II acting on pituitary lactotrophs and circulating catecholamines acting on the $\mathrm{PO} / \mathrm{AH}$ may facilitate prolactin secretion.

The activation of the renin-angiotensin system (RAS) is regulated by the sympathetic nervous system and is mediated by adrenergic receptors $(42,50)$. During stress, excited sympathetic nerves potentiate the activation of the RAS mediated by $\beta$-adrenergic receptors $(42,50)$. Angiotensin II produced from the RAS subsequently facilitates the additional release of noradrenaline from sympathetic nerve endings (42) and of adrenaline from the adrenal medulla (51-53). This is also a positive feedback leading to a stronger excitation and secretion by the sympathetic-adrenal medulla system and a greater release of angiotensin II. This interaction between the two systems in initiating prolactin secretion in response to hemorrhagic stress is in agreement with our data showing that the pretreatment of adrenodemedullated or sympathectomized rats with sarthran blocked the increased prolactin response to hemorrhage.

Angiotensin II has been shown to possess a differential effect on prolactin, since its central administration inhibits and its peripheral administration stimulates prolactin secretion $(12,17,19)$. Whether such opposite central and peripheral effects of angiotensin II on prolactin secretion are physiologically relevant is still unknown. In conclusion, neurochemical studies indicate that central angiotensin II seems to inhibit prolactin secretion by stimulating tuberoinfundibular dopaminergic neurons activity and circulating angiotensin II stimulates prolactin secretion through $\mathrm{AT}_{1}$ receptors at the pituitary level.

Finally, our data suggest a role for circulating catecholamines in the prolactin secretion response to stress. In addition, the experiments reported here demonstrate that RAS has a stimulatory effect on prolactin secretion under circumstances in which sympathetic activity or adrenomedullary secretion is suppressed. These are the first data demonstrating that a physiological prolactin secretion response to stress depends on the RAS.

\section{Acknowledgements}

We wish to thank Ms Jaqueline Pereira Braga for technical assistance and Dr Parlow, National Institute of Diabetes, Digestive and Kidney Disease (NIDDK), for the prolactin radioimmunoassay kit. This work was supported by grants from CNPq, CAPES, and FAPEMIG.

\section{References}

1 Ben-Jonathan N, Arbogast LA \& Hyde JF. Neuroendocrine regulation of prolactin release. Progress in Neurobiology 1989 33 399-447.

2 Castro-e-Silva EJ, Ramalho MJ, Midlej M, Cobas E, Machado A \& Antunes-Rodrigues J. Desipramine blocks stress induced prolactin release in rats. Role of central beta-2-adrenoceptors. Brazilian Journal of Medical and Biological Research 199023 199-204.

3 Darlington DN, Chew G, Ha T, Keil LC \& Dallman MF. Corticosterone, but not glucose, treatment enables fasted adrenalectomized rats to survive moderate hemorrhage. Endocrinology 1990127 766-772.

4 Darlington DN, Keil LC \& Dallman MF. Potentiation of hormonal responses to hemorrhage and fasting, but not hypoglycemia in conscious adrenalectomized rats. Endocrinology $1989 \mathbf{1 2 5}$ $1398-1406$

5 Machado LJC, Mihessen-Neto I, Marubayashi U, Reis AM \& Coimbra CC. Hyperglycemic action of angiotensin II in freely moving rats. Peptides 199516 479-483.

6 Reis FM, Ribeiro-de-Oliveira A Jr, Machado LJC, Guerra RM, Reis AM \& Coimbra CC. Plasma prolactin and glucose alterations induced by surgical stress: a single or dual response? Experimental Physiology $1998831-10$. 
7 Reis FM, Ribeiro-de-Oliveira A Jr, Guerra RM, Reis AM \& Coimbra CC. Blood glucose and prolactin in hyperprolactinemic rats exposed to restraint and surgical stress. Life Science $1996 \mathbf{5 8}$ 155-161.

8 Reis FM, Santos MAR, Reis AM \& Coimbra CC. Effects of hyperprolactinemia on plasma glucose and prolactin in rats exposed to ether stress. Physiology and Behavior 199456 495-499.

9 Ribeiro-de-Oliveira A, Guerra RM, Fóscolo RB, Marubayashi U, Reis AM \& Coimbra CC. Bromocriptine-induced dissociation of hyperglycemia and prolactin response to restraint. Pharmacology Biochemistry and Behavior 200168 229-233.

10 Van de Kar LD \& Blair ML. Forebrain pathways mediating stressinduced hormone secretion. Frontiers in Neuroendocrinology 1999 $201-48$.

11 Yang G, Wan Y \& Zhu Y. Angiotensin II - an important stress hormone. Biological Signals $199651-8$.

12 Diaz-Torga GS, Becú-Villalobos \& Libertun C. Ontogeny of angiotensin II-induced prolactin release in vivo and in vitro in female and male rats. Neuroendocrinology 199459 57-62.

13 Lenkei Z, Nuyt AM, Grouselle D, Corvol P \& Llorens-Cortès C. Identification of endocrine cell populations expressing the AT1B subtype of angiotensin II receptors in the anterior pituitary. Endocrinology $1999140472-477$.

14 Moreau C, Rasolojanahary R, Zamora AJ, Enjalbert A, Kordon C \& Llorens-Cortes C. Expression of angiotensin II receptor subtypes $\mathrm{AT}_{1 \mathrm{~A}}$ and $\mathrm{AT}_{1 \mathrm{~B}}$ in enriched fractions of dispersed rat pituitary cells. Neuroendocrinology 199766 416-425.

15 Steele MK, Negro-Vilar A \& McCann SM. Effect of angiotensin II on in vivo and in vitro release of anterior pituitary hormones in the female rat. Endocrinology $1981109893-899$.

16 Steele MK \& Myers LS. In vivo studies on paracrine actions of pituitary angiotensin II in stimulating prolactin release in rats. American Journal of Physiology 1990258 E619-E624.

17 Yen SH \& Pan JT. Atrial natriuretic peptide negatively modulates the stimulatory effects of angiotensin II on tuberoinfundibular dopaminergic neuronal activity. Neuroendocrinology $1997 \mathbf{6 6}$ 313-320.

18 Dornelles RCM \& Franci CR. Alpha- but not beta-adrenergic receptors mediate the effect of angiotensin II in the medial preoptic area on gonadotropin and prolactin secretion. European Journal of Endocrinology $1998 \mathbf{1 3 8} 583-586$.

19 Ganong WF. Angiotensin II in the brain and pituitary: contrasting roles in the regulation of adenohypophyseal secretion. Hormone Research $19893124-31$.

20 Steele MK, McCann SM \& Negro-Villar A. Modulation by dopamine and estradiol of central effects of angiotensin II on anterior pituitary hormone release. Endocrinology $1982111722-729$

21 Lenkei Z, Corvol P \& Llorans-Cortes C. The angiotensin receptor subtype AT1A predominates in rat forebrain areas involved in blood pressure, body fluid homeostasis and neuroendocrine control. Molecular Brain Research $19953053-60$.

22 Winer LM, Molteni A \& Molitch ME. Effect of angiotensin-converting enzyme inhibition on pituitary hormone responses to insulininduced hypoglycemia in humans. Journal of Clinical Endocrinology and Metabolism 199071 256-259.

23 Scornik AO \& Paladine AC. Angiotensin blood levels in hemorrhagic hypotension and other related conditions. American Journal of Physiology 1964206 553-556.

24 Semple PF. The effect of hemorrhage and sodium depletion on plasma concentration of angiotensin II and [des-asp]-angiotensin II in the rat. Endocrionology $1980 \mathbf{1 0 7} 771-773$.

25 Khosla M, Hall MM, Smeby RR \& Bumpus FM. Agonist and antagonist relationships in 1- and 8-substituted analogs of angiotensin II. Journal of Medical Chemistry 197417 1156-1159.

26 Munoz-Ramirez H, Khosla MC, Hall FM, Bumpus FM \& Khairallah $\mathrm{PA}$. In vitro and in vivo studies of [1-sarcosine, 8-threonine]-angiotensin II. Research Communications in Chemistry Pathology and Pharmacology 197613 649-663.

27 Machado LJC, Marubayashi U, Reis AM \& Coimbra CC. Effect of [1-Sar,8-Thr]-angiotensin II on the hyperglycemic response to hemorrhage in adrenodemedullated and guanethidine-treated rats. Regulatory Peptides 199560 69-77.

28 Mihessen-Neto I, Reis AM, Marubayashi U \& Coimbra CC. Effect of sympathoadrenal blockade on the hyperglycemic action of angiotensin II. Neuropeptides 199630 303-308.

29 Storlien LH, Grunstein HS \& Smythe GA. Guanethidine blocks the 2-deoxy-D-glucose-induced hypothalamic noradrenergic drive to hyperglycemia. Brain Research 1985335 144-147.

30 Harms PG \& Ojeda SR. A rapid and simple procedure for chronic cannulation of the rat jugular vein. Journal of Applied Physiology $197436391-392$.

31 Koshiyama H, Kato Y, Shimatsu A, Mwakami Y, Hattori N, Ishikawa $\mathrm{Y}$ et al. Possible involvement of endogenous opioid peptides in prolactin secretion induced by alpha-2 adrenergic stimulation in rats. Proceedings of the Society of Experimental Biology and Medicine 1989192 105-108.

32 Castro-e-Silva EJ \& Antunes-Rodrigues J. Central adrenoceptors and basal prolactin release in the rat. Hormone Metabolism Research 198921 179-181.

33 Willoughby JO, Day TA, Menadue MF, Jervois PM \& Blessing WW. Adrenoceptors in the preoptic anterior hypothalamic area stimulate secretion of prolactin but not growth hormone in the male rat. Brain Research Bulletin 198616 697-704.

34 Kapoor R \& Chapman IM. Willoughby $\alpha 2$ and $\beta$ adrenoceptors in the mediobasal hypothalamus and $\alpha 2$ adrenoceptors in the preoptic-anterior hypothalamus stimulate prolactin secretion in the conscious male rat. Journal of Neuroendocrinology $1993 \mathbf{5}$ 189-193.

35 Day TA, Jervois PM, Menadue MF \& Willoughby JO. Catecholamine mechanisms in medio-basal hypothalamus influence prolactin but not growth hormone secretion. Brain Research $1982253213-219$

36 Fuxe K \& Hökfelt T. Central monoaminergic systems and hypothalamus function. In The Hypothalamus, pp 123-138. Eds LM Martini, M Motta \& F Fraschini. New York: Academic Press, 1970.

37 Reid IA. Interactions between ANG II, sympathetic nervous system, and baroreceptor reflexes in regulation of blood pressure. American Journal of Physiology 1992262 E763-E778.

38 Zimmerman BG. Adrenergic facilitation by angiotensin: does it serve a physiological function? Clinical Science $1981 \mathbf{6 0}$ 343-348.

39 Belloni AS, Andreis PG, Macchi V, Gottardo G, Malendowicz LK \& Nussdorfer GG. Distribution and functional significance of angiotensin II AT1- and AT2-receptor subtypes in the rat adrenal gland. Endocrine Research 199824 1-15.

40 Dendorfer A, Raasch W, Tempel K \& Dominiak P. Interactions between the renin-angiotensin system (RAS) and the sympathetic system. Basic Research in Cardiology 199893 (Suppl 2) $24-29$.

41 Zimmerman BG. Actions of angiotensin on adrenergic nerve endings. Federation Proceedings 197837 199-202.

42 Kawasaki H, Cline NH \& Su C. Involvement of the vascular reninangiotensin system in beta-adrenergic receptor-mediated facilitation of vascular neurotransmission in spontaneously hypertensive rats. Journal of Pharmacology and Experimental Therapeutics 1984 $23123-32$.

43 Peach MJ, Bumpus FM \& Khairallah PA. Inhibition of norepinephrine uptake in hearts by angiotensin II and analogs. Journal of Pharmacology and Experimental Therapeutics 1969167 291-299.

44 Corwin EJ, Seaton JF, Hamaji M \& Harrison TS. Central role for angiotensin in control of adrenal catecholamine secretion. American Journal of Physiology 1985248 R363-R370.

45 Peach MJ, Cline WH \& Watts DT. Release of adrenal catecholamines by angiotensin II. Circulation Research 196619 $571-575$.

46 Feuerstein G, Boonyaviroj P \& Gutman Y. Renin-angiotensin mediation of adrenal catecholamine secretion induced by hemorrhage. European Journal of Pharmacology $1977 \mathbf{4 4}$ $131-142$. 
47 Jaworski RLP \& Blair ML. Renin response to hemorrhage is augmented by dorsal noradrenergic bundle (DNAB) lesions in conscious rats. FASEB Journal 19984 (Suppl 1) A65-A65.

48 Reid IA. The renin-angiotensin system. Annual Review of Physiology $1978 \mathbf{4 0} 377-410$.

49 Blair ML, Hisa H, Sladek CD, Radke KJ \& Gengo FM. Dua adrenergic control of renin during nonhypotensive hemorrhage in conscious dogs. American Journal of Physiology $199126 \mathbf{2 0}$ E910-E919.

50 Nakamura M, Jackson ED \& Inagami T. Beta adrenoreceptor mediated release of angiotensin from mesenteric arteries. American Journal of Physiology 1986250 H144-H148.

51 Butler DG, Butt DA, Puskas D \& Oudit GY. Angiotensin II-mediated catecholamine release during the pressor response in rats. Journal of Endocrinology 1994142 19-28.
52 Feuerstein G, Boonyaviroj P \& Gutman Y. Renin-angiotensin mediation of adrenal catecholamine secretion induced by hemorrhage. European Journal of Pharmacology $1977 \mathbf{4 4}$ 131-142.

53 Feuerstein G, Boonyaviroj P, Gutman Y, Khosla MC \& Bumpus FM. Adrenal catecholamine response to hemorrhage abolished by an angiotensin antagonist. European Journal of Pharmacology 1977 $4185-86$

Received 22 June 2001

Accepted 14 December 2001 